\title{
The Study About the Women who Lives in Blood Revange Family in Bathore Suburb of Tirana
}

\author{
Natalja Qana \\ PhD student "Institute of European Studies "University of Tirana
}

\author{
Doi:10.5901/mjss.2014.v5n6p477
}

\begin{abstract}
This study will present the results of a qualitative survey conducted in an area of Bathore. It aims to bring to light the socio psychological situation of the women individual, mothers and wives trying to survive the consequences of the blood revenge phenomenon. The subject of this study is a selected group of women from this area. The main objective is to analyze the sociopsychological components of the family relations under the impact of the phenomenon of blood revenge and the possible ways of coming out from this situation. The findings of this study show that this phenomenon makes the life for these women more stressful, more anxious and more insecure. Blood revenges force these women to live with the thought of what will become of their children's lives. There are a number of factors influencing the situation they are in. The study described the statements, discussions, and different opinions and factors such as poverty, the impact of the "Kanun", ignorance, and the chaotic developments of the Albanian society making the life of this targeted group very challenging. The results of this study are derived from a clear analysis of socio-psychological situation created by the impact of the phenomenon of blood revenge and the possibility to come out of it. All this is an appeal to change the miserable situation in which these women live together with their families.
\end{abstract}

Keywords: women, blood revenge, kanun, Bathore, social-psychological situation.

\begin{abstract}
"Revenge today in Albania, has its explanation in its reaction against the strict prohibition by the law during communism and was considered a "good habit" that should be revived. But it was a custom that should not have resurrected. What is happening nowadays has nothing to do with the Albanian Kanun, but is plain barbaric and is carried out with Kalashnikov. It is a great tragedy, sad and must come to an end because is an embarrassment to the Albanian nation. The self-isolation of hundreds of women and children at home because of the feud is terrible, and mind-boggling. This is an old customary legal code, born out of certain historical circumstances. In the absence of a government it is the public opinion that takes a governing role" Ismail Kadare (Kadare, 2001)
\end{abstract}

\section{Introduction}

Major positive changes in the Albanian society during the '90s, towards the democracy, rule of law, open market economy, expansion and implementation of political freedoms and rights were also followed by undesirable phenomenon and steps backward in some directions. The resurgence of illiteracy, inadequate health care, high rate of unemployment, increase of crime rate, the violent self-armament of a part of society, the chaotic urban (Fuga, 2000) development, the inappropriate choice of settlements, arbitrary human intervention on the environment, property disputes, lack of security, corruption in all levels of government, and so on are examples of such negative occurrences. Women's status and position of this period reflects the nature of the changes being carried out, offering opportunities and chances for new life as well as a few new and inherited barriers that must be overcome to meet the challenges of civilization. Not only in Albania, but in all countries that experienced the transition from a centralized economy to that of free market, from a totalitarian society to pluralistic, it is estimated that despite the active participation of women, they are not as well off as the men. Without analyzing the causes of the distant past and those of today, because they are not the subject to this thesis, indicators related to employment, income, immigration, domestic violence, poverty, political representation, etc. show the truth of the above assertion (A Çomo, 2002). It is a general notion that women in Albania have a relatively high level of education. Yet their representation in decision-making, in the local and central government, business, etc. is low. Horizontal gender disparities are noted, which are displayed in the differences between the preferred professions for men and women. There is also vertical gender inequality which is visible in the positions and status between the same professions and is reflected in the low participation of women at all managerial levels The subject of this study became a group of women who has come together with their families, mainly from the north of the country, and has settled on the 
outskirts of Tirana, in an area known as Bathore ${ }^{1}$. Despite their numbers, they represent a segment of the category mentioned above. This subgroup is particularly important because they have left behind their homes where they were born and lived their entire lives, trying to escape the family's feud and have settled just outside the capital to become inaccessible by "hasmi" (the foe). The aims of the study are to shed light on the unimaginable problems of a very specific group of women who suffer everyday the consequences of their self-isolation because of blood-revenge. The phenomenon of blood revenge is not going to be our focus, even though it is impossible not to talk about and assess such a shocking phenomenon of this century. I have focused mostly on the social and psychological consequences of women who are living with it.

Hypothetic question are listed below:

- How much has this "escape" helped these wives and children from the consequences of the feud?

- What is their real situation and their relationship as social beings with the surrounding environment?

- What are the expectations of these the women for their future, especially for their children?

- How much is this group of women and their families identified by the local and central government bodies and are they receiving any kind of support by them?

- How much aware is the society in generally to the existence of these women, their grave situation, the community in which they live?

\section{Methodology}

The aim of the study constitutes of analyzed data obtained from a questionnaire developed for the purpose of this study. Apart from questions to collect complete demographic information, the questionnaire contains 22 other questions organized into several different sections. Besides the demographic character of the data, one of the rubrics aims to determine the family history of self-isolation and its cause, followed by the one about their economic situation and changes, if any, due to migration ${ }^{2}$. Another one deals with family relations centered on the wife and the marital relationships, focusing more on the psycho-emotional aspect. A different rubric is designed to detect their relationships with the community and beyond. The technique that was used is the free interviews with some of the women who chose or were not reluctant to tell the history of their lives. Their number at the beginning was up to 10 , but is included only 4 of them that were assessed to be the most shocking to describe. Two other free interviews conducted with two women whose husbands were not involved in the feud were taken to determine how the latter perceived the position of their friends and families and how sensitive they felt towards them. The questionnaire or survey was conducted with 70 women who lived in Bathore area answered the questions directly addressed to them by the interviewer. In the focused are two focus groups, each with 8 women, whose participants were also women who had not participated in the completion of the questionnaire as well as women who did not have the problem of blood revenge. To have a better representation of the geographical distribution within the area, care was taken that the participating women were of urban $(2,3)$ and rural $(5,6)$ areas of Bathore and most importantly that each women represented only one family. Twelve of the structured interviews were conducted in women's own homes, according to the mediation by the contact person, a lady in whom they themselves and their family members (adult males) trusted. Other interviews were conducted for several consecutive days at the Bathore Community Center. Here were also held the discussions with the two focus groups. The analysis of the data obtained from the questionnaire was done through the software E.pi.INFO, version 3.3.2 2012. The software was provided by CDC (Department of Health and Human Services, Center for Disease Control and Prevention. A valuable resource, particularly for addressing the blood revange as a social and legal problem, were the materials from the national conference ("State and Civil Society in Defense of the Right to Life" organized in 2001 by the State Attorney.) The study based on materials by associations and organizations such as Medica Mondial, (Center for Justice and Peace,) (Center for National Security, Institute for the Development of Habitat,) several other women's associations and an international organizations such as PNUD.

\section{Results}

The survey and interviews were conducted with women residents of Bathore, specifically from four divisions, two from urban areas $(2,3)$ and two from rural areas $(5,6)$. Bathore is today part of the Municipality of Kamza, which represents the largest region among the 11 administrative units of Tirana. Within 10-12 years Bathore turned from formerly an

1 Institute for Habitat Development, Local Agenda for Bathore development, Tirana 2003

2 Annual Report, Institute for Habitat Development, Tirana 2003 
agricultural area to the most populated area of Kamza. Bathore itself is divided into seven areas for development purposes, four of which are part of the urban Bathore (2,3 and 4) and the other three are parts of rural Bathore (5.6 and 7). Most residents are originally from the northeastern part of the country. Their origin is largely from the countryside and their relationships are built on the basis of blood and regional ties. The data on this chart show that all women from selfisolated families are from the northern and northeastern parts of the country. Most of them came from Kukes and the surrounding villages, while a small percentage is from Tropoja and its surrounding villages. It was difficult to create a clear picture of the economic situation of women in isolated families. The women were very unwilling to provide any kind of information about their real financial situation and how their entire families got by. Since women did not want to provide any details on whether or not they paid for the electricity used, whether they possessed any land or other assets in the country of origin, or how could they afford to build the houses they lived in currently, used questions of general character in order to draw any conclusions. To the question, - "Do you think that you can meet the daily needs of your family with the income secured through your employment? - Only 5.3\% answered "Yes" while the other $94.7 \%$ answered simply "No". In real figures it turned out that only two women could make a living by their employment.

The age of participants varies from 22 to 67 years, with an average age of 39.6 years.

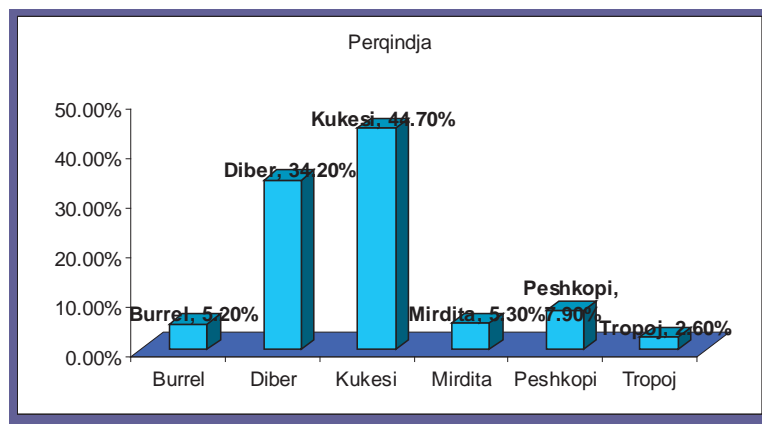

\begin{tabular}{|l|c|}
\hline \multicolumn{1}{|c|}{ Options } & Percent \\
\hline The law & 59.5 \\
\hline The Kanun & 37.8 \\
\hline No opinion & 2.7 \\
\hline
\end{tabular}

\begin{tabular}{|c|c|}
\hline Self-isolation in prior place of living (years) & Percent \\
\hline 1 & 3.6 \\
\hline 2 & 17.9 \\
\hline 3 & 10.7 \\
\hline 4 & 28.6 \\
\hline 5 & 21.4 \\
\hline 6 & 7.1 \\
\hline 11 & 3.6 \\
\hline 12 & 3.6 \\
\hline 15 & 3.6 \\
\hline
\end{tabular}

According to the questionnaire there were eight women whose families had not had problems with blood revenges in their previous place of residence. So animosity and consequently the blood revange started after arrival in Bathore. This was very hard on them because they had come here in search of a better life. This shows that environment, although important, is not the determinant factor in this phenomenon. "Kanun" either. Causes of conflict were often as banal as bickering of young people who - as evidence of women-not only did not recognize the Kanun (Durham, 1991), "I do not know, I only heard from the mother," but knew nothing of its rules or twisted them, causing a chain of killings that stretched even to distant cousins and did not seem to end.

A very small number of women stated that they were in blood for many years, and even when they had gotten married they had found the family already in the blood revenge and the shadow of the vendetta continues to pursue them everywhere they go. Despite being few in numbers, their burdens were even worse because as they would say, "it seems that we are born with the fear of death over our heads. 


\begin{tabular}{|l|c|}
\hline \multicolumn{1}{|c|}{ Cause of self-isolation } & Percent \\
\hline Husband has killed & 7.8 \\
\hline Husband is killed (Son in self-isolation) & 13 \\
\hline Uncle has killed & 2,6 \\
\hline Old feud & 10.5 \\
\hline Son is killed & 5.2 \\
\hline Brother-in-law has killed & 10.4 \\
\hline Brother-in-law is killed & 2,6 \\
\hline Cousin is killed & 2,6 \\
\hline Husband's cousins have killed & 7.8 \\
\hline Father-in-law has killed & 21 \\
\hline Husband's uncle has killed & 13.2 \\
\hline
\end{tabular}

A high percentage of women have responded in favor of the law, because according to them, law can do much more the Kanun. On the other hand, another considerable part of the women 37.8\% responded in favor of the Kanun. Questions about this response revealed that this had to do with the fact that they see to the implementation of the Kanun an opportunity for reconciliation, which cannot be found in law, because the law punishes the killer so far has done nothing. (Nobody had heard that there is a law on mediation) Focus group discussions about Kanun proved once more that the young people know almost nothing or have little respect for the real laws of Kanun and that much effort were made to reconcile both sides and even when an agreement for peace was reached between two families in blood the peace get violated again. While the very small portion of women who chose the "no opinion" option, explained that this was because they have no hope either in law or in Kanun" It will get better, and I think that my life will be different and better"

M - "I am afraid of murder, rape, or being held hostage. I am afraid to even step out"

M-"I accept it. What can I do? It is very difficult to live in fear all the time and to live with the fact that my oldest brother is not with us anymore but lying in the ground.

M-"I felt compassion" - she says, many times I cry when she cries "I often hide in any corner of the house and cry alone. I am afraid when mother starts crying because I know that she always gets really concerned about my big brother.

M - "I will not forgive the blood. The government cannot do anything about it. I will kill my family's enemy by placing dynamite in their house. I cannot take this any longer. It is very difficult to live like this".

They would not tell of any plan or intention of their own, to change the situation, although they experienced great concern for the future, not that of themselves, but of their children. Responses showed that women not only did not seek a way out, but that did not have any confidence that something can be done, or felt completely powerless about it. A second common characteristic of their responses was hope. Most of them hoped that the future would be better, but God's help (23.4\%) they hoped that their blood would be spared (28.6\%).

\section{Conclusions and Recommendations}

The blood revenge continues to be a phenomenon present in the Albanian society. Even after 20 years of existence, the democratic government has failed to place under control this phenomenon in terms of its criminal dimension. Uncontrolled movements of population carried the phenomenon of blood revenge in other areas of the country, where it was not known before such as Tirana and Durres. Overpopulation is in itself a favorable premise for keeping it alive and creating new cases.

This study in Bathore suggests that not only in those areas where the blood revenge was traditionally known to exist, but even in those areas populated during the years of political transition in Albania, where the phenomenon is carried, social groups of isolated families are created. Part of this group are women and children in Bathore, who, despite the change in location, continue to suffer the tragic drama of the feud, hidden from the aim of their enemies, and at the same time away from the eye and attention of the government and society. Quick identification, and in a broader plan the registration of each case by the government can avoid many negative consequences. The blood revenge is coupled with poverty. In most of the cases is a consequence of poverty, but at the same time is a source of poverty. Most women that were interviewed lived in complete poverty. The employment of this category of women should be priority of the government. Living with self-isolated family members, detached from the social developments, in deep poverty and isolation has brought about and continues to bring irreparable consequences on their psycho-emotional state. Such living conditions are premises that not only promote feelings of hatred and revenge but also favor the passing of such feeling from generation to generation, which turns the blood revenge into a vicious cycle. Analysis of the group of women of such 
families indicates that they are characterized by the passivity and compliance with their situation, and the negative emotions of fear, anxiety, and helplessness to change the course of their lives and their children's lives. They are wives who suffer the unavailability of their husbands that are candidates of the murder or dead spouses who continue to cause pain. They are mothers who do not enjoy seeing their children grow up and are living victims who live as if they do not exist.

\section{References}

Annual Report, Institute for Habitat Development, Tirana 2003

Çomo, A. Fading, G. Totozani, D. (2002). The feud, mental health and the role of nongovernmental organizations in the fight against this phenomenon, Tirana.

Durham, E. (1991). The plague of the Balkans and other works for Albania and Albanians. Tirana.

Fuga, A. (2000). Conflicts in urban areas and their resolution through mediation. tirane.

Institute for Habitat Development, Local Agenda for Bathore development, Tirana 2003

Kadare, I. (2001). Life and Law magazine . 